http:/ /dx.doi.org/10.1590/0104-07072017003840015

\title{
THE CONTRIBUTION OF IMRE LAKATOS FOR EPISTEMOLOGICAL ANALYSIS OF THE BRASÍLIAN NURSING POSTGRADUATE PROGRAM
}

\author{
Gilberto de Lima Guimarães ${ }^{1}$, Tania Couto Machado Chianca², Vania Regina Goveia3, Isabel Yovana Quispe \\ Mendoza $a^{4}$ Selme Silqueira de Matos ${ }^{5}$, Ligia de Oliveira Viana ${ }^{6}$
}

${ }^{1}$ Ph.D. in Nursing. Professor, Departamento de Enfermagem Básica, Escola de Enfermagem da Universidade Federal de Minas Gerais (UFMG). Belo Horizonte, Minas Gerais, Brazil. E-mail: drgilberto.guimaraes@hotmail.com

2 Ph.D. in Nursing. Professor, Departamento de Enfermagem Básica, Escola de Enfermagem, UFMG. Belo Horizonte, Minas Gerais, Brazil. E-mail: taniachianca@gmail.com

${ }^{3}$ Ph.D. in Nursing. Professor, Departamento de Enfermagem Básica, Escola de Enfermagem, UFMG. Belo Horizonte, Minas Gerais, Brazil. E-mail: vaniagoveia@ufmg.br

${ }^{4}$ Ph.D. in Nursing. Professor, Departamento de Enfermagem Básica, Escola de Enfermagem, UFMG. Belo Horizonte, Minas Gerais, Brasil. E-mail: isabelyovana@ufmg.br

${ }^{5}$ Ph.D. in Nursing. Professor, Departamento de Enfermagem Básica, Escola de Enfermagem, UFMG. Belo Horizonte, Minas Gerais, Brazil. E-mail: selmesilqueira@gmail.com

${ }^{6}$ Ph.D. in Nursing. Professor, Escola de Enfermagem Anna Nery, Universidade Federal do Rio de Janeiro. Rio de Janeiro, Rio de Janeiro, Brazil. E-mail: ligiaviana@uol.com.br

\begin{abstract}
Objective: to present the theoretical perspective of Imre Lakatos, from its Methodology of Scientific Research Programs, and its epistemological evaluation of the Brazilian Postgraduate Nursing Program.

Method: It is a reflexive analysis, organized into three sections, with the following question: Can the theoretical-philosophical proposition by Imre Lakatos contribute to assess to the Brazilian Postgraduate Nursing Program?

Discussion: It is assumed that nursing care as a theoretical hypothesis; it presents the basic elements of lakatosian program: the hard core, the protective belt, negative and positive heuristics and its application for evaluation of Brazilian Postgraduate Nursing Program. Program researchers must define and establish the lakatosian basic elements. After 43 years of the creation of the stricto sensu postgraduate programs in Brazil, a critical analysis of its epistemological foundation is necessary.

Conclusion: the amplification of the evaluation process from the link between quantitative and philosophical in order to judge the Nursing Science is recommended.

DESCRIPTORS: Nursing. Knowledge. Philosophy. Evaluation of research programs and tools.

\section{A CONTRIBUIÇÃO DE IMRE LAKATOS PARA A ANÁLISE EPISTEMOLÓGICA DO PROGRAMA BRASILEIRO DE PÓS-GRADUAÇ̃̃O EM ENFERMAGEM}

\section{RESUMO}

Objetivo: apresentar a perspectiva teórica de Imre Lakatos a partir de sua Metodologia dos Programas de Pesquisa Científica e seu uso avaliativo-epistemológico do Programa brasileiro de Pós-Graduação em Enfermagem.

Método: trata-se de uma análise reflexiva, organizada em três seções, tendo a seguinte questão norteadora: a proposição teórico-filosófica de Imre Lakatos pode contribuir para avaliação do Programa brasileiro de Pós-Graduação em Enfermagem?

Discussão: Assume-se o cuidado de enfermagem como hipótese teórica; apresenta os elementos basilares do programa lakatosiano, a saber: núcleo duro, cinturão protetor, heurística negativa e heurística positiva; e sua aplicabilidade para avaliação do Programa brasileiro de PósGraduação em Enfermagem. Cabe aos pesquisadores que atuam no Programa, definir e estabelecer os elementos basilares lakatosianos. Transcorridos 43 anos da criação da pós-graduação stricto sensu no Brasil, faz-se necessário criticar seu fundamento epistemológico.

Conclusão: advoga-se a ampliação do processo avaliativo a partir do enlace entre o quantitativo e o filosófico a fim de ajuizar a ciência da enfermagem.

DESCRITORES: Enfermagem. Conhecimento. Filosofia. Avaliação de programas e instrumentos de pesquisa. 


\section{LA CONTRIBUCIÓN DE IMRE LAKATOS PARA EL ANÁLISIS EPISTEMOLÓGICO DEL PROGRAMA DE POST-GRADO EN ENFERMERÍA DE BRASIL}

\section{RESUMEN}

Objetivo: presentar la perspectiva teórica de Imre Lakatos apartir de su Metodología de Programas de Investigación Científica y su uso de evaluación epistemiológica del Programa de Post-Grado en Enfermería Brasileño.

Metodo: se trata de un análisis reflexivo, organizado en tres secciones, guiados por la siguiente pregunta: ¿la proposición teórico-filosofica de Imre Lakatos puede contribuir para evaluación del Programa brasilero de Post Grado en Enfermería?

Discussión: se asume el cuidado de enfermería como hipótesis teórica; se presentan los elementos básicos del programa lakatosiano: núcleo duro, cinturón protector, heurística negativa y heurística positiva; y su aplicabilidad para evaluar el Programa de Post-Grado en Enfermería de Brasil, definir y establecer los elementos básicos lakatosianos. Después de 43 años de la creación del post grado stricto sensu en Brasil, se hace necesario criticar el fundamento epistemiológico.

Conclusión: defiendese la ampliación del proceso de evaluación a partir del enlace entre el cuantitativo y lo filosófico a fin de juzgar la ciencia de enfermería.

DESCRIPTORES Enfermería. Conocimiento. Filosofía. Evaluación de programas e instrumentos de investigación.

\section{INTRODUCTION}

The first stricto sensu post-graduation Nursing course in Brazil was created in 1972 at the Anna Nery School of Nursing, starting with the M.Sc. level. In 1982 the first doctoral program was approved in the area, in the University of São Paulo, through the partnership between two schools, one located in the capital and another in the city in Ribeirao Preto (Brazil). Later, in 2002, the first Master's degree for professional career was created under the mentorship of Escola de Enfermagem Aurora Afonso Costa, belonging to the Universidade Federal Fluminense. ${ }^{1}$

Today, there are 98 post-graduate studies courses, over 50 Masters courses, $33 \mathrm{PhD}$ courses and 15 Vocational Master courses, in Brazil throughout the national territory. These data reveal the progress that the Graduate Program in Nursing (PPGENF) has achieved in the country, mainly from a reduction of regional disparities in the distribution of courses and obtaining concepts of academic excellence by some programs. From a quantitative point of view, the PPGENF supports the proposal for the formation of human resources for care, teaching and Nursing research.$^{2-4}$

Thus, it can be seen that the advent of postgraduate courses has contributed to the establishment of the scientific corpus of the profession through research activity, established as an essential criterion for obtaining the M.Sc. and PhD title. ${ }^{3,5}$

Therefore, it is vitally important to understand the social function, politics and science of PPGENF in order to form Masters and Doctors in nursing, with high qualifications, intellectual productivity and social inclusion, in adequate amounts which can form the staff of the faculty, allowing growth and development of the profession and teaching their care practice in Brazil. ${ }^{3-5}$

Given this historical construct, there is a lot to celebrate. However, one should, from now on, give tangible concern to reaching the truth of the knowledge that addresses the philosophy of science and epistemology, putting the Nursing scientific corpus construct under critique, which so far has been undertaken by the PPGENF because, after all, it is the responsibility of the researcher, to provide tools to critique his own conception. ${ }^{5}$

The search for such a critical foundation occurs, because the professional knowledge is under pressure to maintain a high level of post-graduate stricto sensu studies. Concern marked by vicissitudes of practice research, especially required by science and technology policies from a transplanted from Natural Science guidelines, despite the established peer remodeling, its guiding character remains preserved. ${ }^{5-7}$

This fact has a historical basis for modern science, as a human endeavor, the sparked stimulus to know the empirical world and in this case, Physics excelled as a criterion for its verification and development, which moved the other fields of knowledge, during the late nineteenth and twentieth century, in the establishment of criteria that could reestablish employees to this area of knowledge. Due to research practice and producing knowledge, Nursing is evaluated with requirements of the established sciences.

However, the scientific truth arising from this field of knowledge was the scene of a strong epistemological crisis, notably, from the first decades of the twentieth century, with the implications arising from the theory of relativity and quantum physics, putting two hundred years of evolution of 
knowledge from Newtonian physics under critique. Thus, the rupture and the undoing of certainty, can be seen to emerge. Therefore, there is no reason to believe that the foundations of today identified as foundational of the construction of nursing knowledge cannot be doubted and critiqued.$^{4-7}$

Currently in Brazil, the strictu sensu post graduate courses are evaluated systematically by the Coordenação de Aperfeiçoamento de Pessoal de Nivel Superior (CAPES), under the Ministry of Education, which appoints a committee of experts in each field of knowledge, which is responsible for the allocation of concepts ranging from 1 to 7 to the program. Concepts 6 and 7 are allocated to programs of excellence and should be the goal to be achieved by all actors working in different PPGENF. Programs that achieve this distinction, in addition to the criteria, indicators and metrics common to all programs need to meet certain specifications. As a career linked to the current scientific paradigm, Nursing has similar criteria for evaluation to other areas, which, in the view of some career researchers, promotes the visibility and recognition of its scientific nature. ${ }^{3-5}$

Historically, Brazilian Nursing is a career based on the Nightingale system which is based on the US system and assumes philosophical alignment that is consistent with this reference, imposing a evaluative perspective on itself. Therefore, in the Brazilian context, there is the movement to an ideological approach of the guidelines proposed by the American Association of Colleges of Nursing (AACN) for Doctoral career programs. ${ }^{8}$

Among the criteria established by the AACN are: 1- faculty: there must be a diversity of origin and intellectual perspectives; 2 Study program: must be clear and available to students, and the course content must address philosophical and historical foundations for the development of nursing knowledge; 3- resources: human, financial and institutional which must be available to meet the objectives of the course; 4 students: must be selected from a pool of candidates with academic and professional profiles of competence and quality, and their subjects must maintain proximity to the experience of the faculty; 5- evaluation must be carried out systematically, continuously, in order to meet the outlined program goals and objectives, attending to an analytic which does not finish in the quantification, but which seeks to understand qualitative elements. ${ }^{8}$

In the case of PPGENF analysis at the level of excellence, CAPES is responsible for the final evaluation committee report, to identify and value, the programs that meet the skills in the areas of Solidarity, Nucleation, Leadership and Internationalization (scientific production and international participation), every four years. ${ }^{2-3,9-10}$

As for Solidarity, it is understood as the movement of cooperation with other programs graded 3 or 4 , or groups that still do not have postgraduate graduate studies, thus aiming to reduce the imbalances between the different regions and countries with less developments in graduate schools, attending to new areas of knowledge promoting and consolidating post-graduate courses. ${ }^{2,9}$

The nucleation area is characterized by the ability to form critical and reflective students capable of becoming researchers, educators and leaders in health and its professions. This perspective requires the PPGENF to develop monitoring methodology of their graduates ${ }^{2,9}$

Leadership is identified by PPGENF's ability to be recognized by members of the scientific community and the profession as relevant to the construction of scientific corpus of nursing, mainly identified from the promotion of post-doctoral internships, participation of its faculty in area committees in agencies which support research and cooperation with other research centers on an international level., ${ }^{2,9}$

In Internationalization, the activities developed by teachers and students in programs, as well as their scientific productions linked to journals abroad are all included. Thus, the participation of teachers and students abroad are evaluated, such as visits and exchanges in the programs; split Ph.D.; post-doctoral training; student guidance from the programs; post-doctoral internship orientation, among others; and in the field of scientific production, intellectual productions published in media outlets with international circulation, taking into account the impact factor for the area., ${ }^{2,9}$

Given this situation, it can be inferred that internationalization must be understood not as a means but as an end. Its practical effect is to allow the relationship of the various social actors in the global society to be without borders and grounded in knowledge. Nevertheless, it is present in government agendas and encourages the university to assume that commitment. ${ }^{11}$

Despite all efforts and commitment in the evaluation of PPGENF, the perspective of Philosophy of Science and Epistemology is not contemplated. Considering all the advances and achievements obtained during the historical process of PPGENF, it is necessary to criticize the epistemological 
foundations which exist and consider them in the evaluation process. ${ }^{5,12}$

Thus, it is important to proceed to an evaluation process which associates the criteria, indicators and metrics used by CAPES, in epistemological aspects. This incorporations will allow the subjects who act in PPGENF to criticize the basis on which the Science of Nursing is being built on, enabling them to ratify or rectify the choices made. This analysis should take place based on a theoretical and philosophical framework. $2,9-12$

It is known that such an assessment is abstruse to be carried out, because what is at issue is the validation of PPGENF under the epistemological point of view resulting from production of dissertations and theses, evaluating it under the conceptual and philosophical viewpoint which it is based on. . $^{2.9-10}$

There is no doubt that it is a major project which has its value in the action to reveal the phenomenon that was developed, permitting the PPGENF to be ratified or rectified. Put like that, there is no secondary alternative, it is necessary to advance in the evaluative aspect, aiming to criticize the PPGENF so that it can safeguard the basis for the construction of Nursing Science. ${ }^{2,5,9}$

Thus, this article aims to present the theoretical perspective of Imre Lakatos from its Scientific Methodology Research Programs ${ }^{13}$ and its epistemological evaluative use of the Brazilian Program Graduate Nursing (PPGENF).

In order to develop this reflection, the following guiding question was formulated: Can the theoretical and philosophical proposition, Imre Lakatos, contribute to the evaluation of PPGENF?

In the search for its elucidation, reflective analysis is arranged in three sections. The first is the theoretical perspective of nursing from the identification of some elements that founded the Nightingale model. Therefore, we used national epistemological productions related to the valuation of Modern Nursing and the characteristics of that model, aiming to identify the subject matter of the profession and thus extract the title of exemplification, the foundational hypothesis, ie the core of PPGENF. The second presents the basic elements of the theory of Imre Lakatos, namely: hard core, protective belt, negative and positive heuristic; and, finally, its applicability to epistemological evaluation of the PPGENF. ${ }^{4-5,13-16}$

\section{DISCUSSION}

\section{The elements that form the Nightingale model}

Florence searched for a break of the nursing practice in its modus operandi at work, in care and education. Therefore, in contrast to the paradigm of her time, she sought to promote proximity between nursing and science. Thus, it incorporated the requirements of the new scientific rationality and the epidemiology as a tool for the reasoning of nurse education. ${ }^{14}$

In the field of division of labor, the model proposed by Florence, highlights the dichotomy that was born into nursing, between intellectual and manual work, identified in figures of lady-nurse and nurse. The first was in charge of conducting the process of organizing, supervision, leadership and instruction. Possessing a privileged socioeconomic and cultural status in English society. The nurse had the responsibility of implementing manual labor and had a lower society class. ${ }^{14}$

In the field of healthcare practice, Florence described watching people as a modality, stating that the nurse should develop strict observation and solidarity skills. Through these tools, she established the methodology for implementing nursing care. ${ }^{14}$

It appears that, after employing the method of observation, Florence went on to evaluate the characteristics of the environment and its impact on the health-disease of the patient. She pointed out that the environment needed to be seen in a comprehensive manner in order to promote the recovery of the sick. She defended the proposal that it should have good conditions to receive the patient, with respect to aeration, lighting, cleaning and heating. Florence's use of empirical method allowed her to lay the foundation for the construction of which, contemporaneously, came to be identified as the environmental of theory of nursing. ${ }^{15}$

In the field of education, Florence promoted the introduction of candidates to Nursing, who possessed a "good-nature". This action provided the improvement of the level of care, strengthening the construction of the figure of the nurse as guardian of morals. Thus, it was built to identify females as model representatives. She established the hospital setting as a theoretical and practical learning field, noting also that the nurse should not be subject to medical interference. ${ }^{16}$

From these three fields, Florence determined the pragmatic career, a base centered on science and art, understood as a set of rules and actions capable 
of directing human activity, expressed by nursing care. Such inference can be obtained from its effective commitment to give the nurse competence and skill to take care of the sick, paying attention to the use of scientific knowledge and technology, combined with the understanding of the human and solidarity. $5,12,14-20$

Thus, Nightingale nursing care, employed in this study as synonymous with nursing care, based on science and art, expressed by the caring attitude to the patient and the community is the essence of the profession and therefore it is advocated that it should be the object of study. ${ }^{5,12}$

\section{The methodology of Imre Lakatos scientific research programs}

Primarily, it is necessary to present the Popper falsifiability, because it will be his Lakatos which will establish its methodology in Scientific Research Programs. The falsifiability sees science as a set of hypotheses that are experimentally proposed in order to accurately describe or explain the world of behavior and the universe. One hypothesis is unforgeable if there is a proposition of observation or a combination of them logically possible that are inconsistent with it, that is established as true which falsify the hypothesis. ${ }^{7}$

As a disciple of Karl Popper, Lakatos developed its description of science as an attempt to overcome the criticism of the master falsifications. Its interest is to identify the elements that underlie the scientific research program and its historical description and thus evaluate it in light of its central thesis. ${ }^{7}$

In this sense, the Lakatosian research program is a framework that provides guidance to the scientific community because it allows the graduate program and its results to be evaluated along the continuum of its existence, and also point the direction for current researchers and those who will join them. It consists of four basic structural elements, namely: The core, protective belt, negative and positive heuristic. ${ }^{13}$

The core is the defining characteristic of the Lakatosian scientific research program and takes the form of a general theoretical hypothesis which is the basis on which the program is developed. The core provides the program's identity and thus to remove it or change it, would reduce it to an inconsistent theoretical plot. It is the foundational theoretical premise of that program, consensualized by the protagonists, considered unfalsifiable. In turn, the core is obtained, this assumes the function of supporting the entire program, considered an immutable element. Therefore, applicants must have the necessary clarity to its formulation, recognizing the amplitude and extension. ${ }^{13}$

The core is the vital and unifying element of the Lakatosian scientific research program and any inadequacy in the correspondence between the research program and the observation data should be attributed not to the assumptions which constitute it, but to some other part of the theoretical framework. The plot of assumptions which make up this other part of the structure is what Lakatos called the protector belt.$^{13}$

The protective belt is the second element of the Lakatosian research program. It consists of the explicit auxiliaries which supplement the core as well as the assumptions underlying the description of the initial conditions and the observational propositions. These cases serve as a shield to prevent the observed facts and not the elucidated ones, which come to reach the core. Thus, these are auxiliaries which may be replaced or reshaped, however, they fulfill the function to support the nucleus and, in this way, it will remain intact. ${ }^{7,13}$

The third element is the negative heuristic. It is a requirement which during the development of a scientific research program, the core must remain intact and unmodified. It involves the stipulation by the researchers that the basic assumptions of the program, ie its core, will not be rejected or modified. The core should remain protected from falsification by the protective belt. This is the core of negative heuristics. ${ }^{13}$

By introducing the negative heuristic as a constituent of scientific research program, Lakatos is valuing the permeating political dimension. Thus, for it, the research program is the result of consensual unity of the protagonists. Thus it emphasizes the conventional element connected to the work of researchers within the program, based on the recognition that they, as political subjects, must decide freely to accept the core, promoting and committing to its stability and continuity.$^{13}$

The fourth component is the positive heuristic. It is the aspect of the program which shows the researchers what should be done, rather than not be done, it is more vague and difficult to characterize specifically than the negative heuristic. It consists of a general pattern that indicates how the research program can be developed. ${ }^{13}$

Given the above, it is noteworthy that within the theoretical frame, Lakatos is the prerogative that one must discuss along the way, accepted by 
somebody who can promote change in the protective belt and heuristics. This procedure is useful to maintain the research program, assuming localized difficulty as it will propose new referrals that may favor the discovery of solutions. ${ }^{13}$

In this perspective, the Lakatosian proposal should be discussed from two points. The first is for the work to be done within the research program, the other is the comparison of competitive research programs. In the first, it will be up to researchers to develop the program from the formulation of hypotheses for the protective belt. It will be them who will allow the expansion of the program. The second relates to modifications to the protective belt that should be allowed by the program and which types should be excluded as non-scientific. Lakatos is incisive: any modification is allowed, provided it is not ad-hoc, ie, modifications must be able to be tested, because only then will the discovery of new knowledge be possible. ${ }^{13}$

\section{The applicability of Lakatosian proposal as an epistemological evaluation instrument of PPGENF}

Putting into consideration, in relation to the nursing object of study and methodology of the theoretical research programs, it is necessary to demonstrate how the Lakatosian proposal could be constituted as an evaluative instrument to PPGENF from the use of its founding members, namely: the core, protective belt, negative and positive heuristic. ${ }^{13}$

Thus, for there to be epistemological evaluation of the PPGENF from a Lakatosian proposal, it is necessary that the cooperating researchers set the goal of identifying the core. In this regard, they must carry out the ontological exercise, aiming to achieve the essence that founded the program. This exercise allows them to criticize and reflect on the the famous question: what is it?

That when executed, it will be required to obtain their responses, the intellectual effort of the researchers, aiming to dispel doubts, contradictions and, with the everyone's consent, they will carry out the conceptual elaboration of the core. . $, 5,9-10,13^{-13}$

Thus, the formulated core will be presented in a clear precise hypothesis, that will give meaning and significance to PPGENF. The core will be able to accurately express the essential elements that underlie the PPGENF, making it possible to establish from it, the program's goal, its area of concentration, lines and research projects and body disciplines. ${ }^{3,9-10,13}$
This study postulates the hypothesis that the core of PPGENF is nursing care based on science and art, expressed by a caring attitude towards the patient and the community. This characteristic was inferred from its identification as a tool that allows nurses to assist the individual who experiences the binomial of health versus disease in various stages of the life cycle and therefore accepted as the object of study. ${ }^{5,12,14-16}$

It can also be accepted that from a formal point of view, the area of concentration of PPGENF could constitute the core, provided it is explained in a clear and precise manner, preferably in the form of hypothesis. Thus, any research that is linked to the program will have to obligatorily be subject to the matrix which forms the identified core. ${ }^{3,5,13}$

The protective belt is the second element of the Lakatosian research program. It is composed of explicit auxiliary hypotheses that supplement the core. The PPGENF researchers must, after determining the core, identify or establish the hypotheses that are linked to it, with the purpose of complementing, and it is them who make up the protector belt. ${ }^{13}$

One can propose by way of example, some hypotheses, among others, that make up the protective belt, namely nursing care and its insertion into the Brazilian health policy; nursing care and vocational training; and nursing care and its theoretical and philosophical relationship to the systematization of Nursing care.5,12,14-16

Thus, it appears that the assumptions keep a close relationship with the core and supplements in its scope, because it proposes a formulation that makes it increase. If, after conducting further research, there is a rejection of the auxiliary hypotheses, this refutation demonstrates its fragility to explain certain phenomenon. In our view, their mistake was to extend the core to an incompatible field with its essence. Therefore, the failure to explain the phenomenon is rooted in the assumption that constitutes the protective belt. It failed in its mission to protect the core. However, this refutation will not contaminate it, because falsification is limited to the auxiliary hypothesis that after tested, proved falsified. ${ }^{13}$

In this sense, supplementation was shown to be inconsistent and a new hypothesis to replace that failed to protect the core. Perhaps a new question arises, namely: what is the importance of this? Its value is twofold. The first is that the research program is active and its core preserved and, consequently, in this condition, the program's identity is safe. It continues to hold its founding elements that 
give it meaning and significance. Soon, it will also be possible to remain and bring light to the theoretical explanation of the phenomenon. ${ }^{13}$

The second is that the failure of the protective belt allows the review and, in the process, it builds knowledge. Thus, the loss of the hypothesis of the protective belt is beneficial to the development of the science of nursing, because it points to the chosen path which should be revised or replaced, allowing the reworking of knowledge. ${ }^{6}$ Thus the Baconian proposition was rediscovered which states that science develops from their mistakes because they allow the journey to be undertaken again and opens up new possibilities. ${ }^{12,21}$

To illustrate hypotheses for the protective belt, the direct correlation of these with the postulated core was sought. One can then understand the hypotheses that comprises the protective belt may constitute lines of research of the PPGENF. By doing so, the relationship between the core/concentration area, the protective belt / lines of research remain and indicate the path for the development of the disciplines in the Graduate Program, as well as research projects that it is connected to. ${ }^{5}$

The third element is the negative heuristic and its function is the democratic discussion, targeting the preservation of the core and therefore the identity of PPGENF. If perhaps there is a conceptual change of the core, the program has decreed its end and a new theoretical model is proposed. Put like that, the core is unchanged by convention and there is a change, PPGENF ceases to be what it proposed. Therefore, the core should be clear and objective and the changes should be confined to the protector belt. ${ }^{13}$

Thus, researchers from the PPGENF should remain as a conceptual unit group in this stage, that is, they will have periodically bring the value attributed by them to the hard core.${ }^{13}$ Also considering it is believed that now the occurrence of an new question, namely: what does it mean?

It is likely that over the historical development of the research program, there has been intellectual renewal within the group of researchers, not in its formal aspect, but conceptual. At this time, the general hypothesis that establishes the core becomes a critical target and begins the process of judging regarding the suitability of the core. Therefore a pro-change movement of the core may occur. If this change proceeds, the PPGENF loses its identity. Hence the need for negative heuristics, because it is first of all an attitude of critical and continuing consideration by PPGENF researchers. It provides the design and the reaffirmation of the covenant established around the core and keeps the protector belt up to date and, under criticism. ${ }^{13}$

The fourth is positive heuristics and it is the aspect of the program which recommends and indicates actions to the researchers which they will seek to develop. It is through a general agenda drawn up by the participants from the democratic debate, which indicates how PPGENF can be developed. Accordingly, it advocates that this agenda should include the pursuit of academic excellence proposed by CAPES, from obtaining the program concepts 6 and 7. Therefore, it is up to researchers, to mobilize efforts to establish policies and strategies for entire teaching staff, in order to acquire skills and expertise to grow and develop the areas of Solidarity, Nucleation, Leadership and Internationalization (scientific production and international participation). This fact is based on the premise that PPGENF of excellence should be concerned with the growth and academic development of all researchers and students..$^{22-23}$

\section{FINAL CONSIDERATIONS}

At the end of this reflexive analysis, it can be said that from the point of view of the Philosophy of Science and Epistemology, it is necessary to put the construct of the scientific profession corpus from PPGENF under review, attempting to legitimize and justify the knowledge of nursing so far. Therefore, researchers who work in PPGENF should search together for the already established methodological guidance to enable them to undertake this review. Thus, it makes the judgment that the theoretical-philosophical framework proposed by Imre Lakatos, already applied to the epistemological analysis of the Physical Sciences, to support this venture. The Lakatosian program has four components: hard core, protective belt, negative heuristic and positive heuristics.

In this study, it is argued that nursing care should be at the core of PPGENF, having its foundation in the Florence Nightingale way of thinking. This fact is rooted in historical and philosophical uniqueness that is its legacy, imposing on the history of nursing, a unique division to the achievement of Modern Nursing, which the current nurse becomes heir to.

Therefore, it is up to researchers working in PPGENF to define and establish the elements of the program. In this way, all intellectual productions should keep a close relationship with the core of PPGENF. 
Thus, the intellectual production of PPGENF, obtained from dissertations and theses, will be continuously confronted with the hard core, in order to be identify its consistency or lack of. It is of note, in this way, that the attention should be given to this assessment, it is its constitutive nature to guide the intellectual production of PPGENF, allowing it to keep intrinsic relationship to the core. Such an attitude incisively combats any epistemological deviations that may arise in PPGENF, preventing the removal of the core research. This process is important, given that its implementation maintains the cohesion and the internal coherence of the program. Only then, the Science of Nursing will develop and strengthen.

It is believed that only through the expansion of the evaluation process, joining the quantitative and theoretical and philosophical, that it can critically and reflectively judge the soundness of the epistemological foundation that is used to build the Science of Nursing.

It remains that the actors participating in the construction of PPGENF make efforts which exceed the requirements of the evaluation process conducted by CAPES, appropriating the theoreticalphilosophical knowledge arising from the Philosophy of Science and Epistemology, in order to discuss ways that constitute the modus operandi of their programs. Such action will enable them to identify, ratify or rectify the choices made for the building of the scientific corpus of Nursing.

It is noted that the criteria, indicators and metrics used by CAPES, is not abdicating the criteria, but proposing the extension of the evaluation process, understanding that it is the responsibility of researchers and other actors involved in PPGENF to propose forms of criticism of the knowledge produced, aiming to thus safeguard the foundations on which they are building the Science of Nursing.

\section{REFERÊNCIAS}

1. Scochi CGS, Munari DB. A pós-graduação em enfermagem brasileira faz quarenta anos: avanços, desafios e necessidades de novos empreendimentos. Esc Anna Nery Rev Enferm [Internet]. 2012 [cited 2015 Jan 20]; 16(2):215-8. Available from:http:/ / www. scielo.br/pdf/ean/v16n2/01.pdf

2. Coordenação de Aperfeiçoamento de Pessoal de Nível Superior. Relatório de Avaliação 2010-2012. Trienal 2013. CAPES [Internet]. 2013 [cited 2015 May 12]. Available from:https:/ / docs.google.com/viewer? $\mathrm{a}=\mathrm{v} \& \mathrm{pid}=\mathrm{si}$ tes\&srcid=Y2FwZXMuZ292LmJyfHRyaWVuYWwtM jAxM3xneDo1MDYyMTg4ZmYxYTk4MWUw
3. Erdmann AL, Fernandes JD, Lunardi VL, Robazzi MLCC, Rodrigues RAP. O alcance da excelência por programas brasileiros de pós-graduação stricto sensu com doutorado em enfermagem. Texto Contexto Enferm [Internet]. 2012 [cited 2015 Jan 20]; 21(1):1309. Available from:http://www.scielo.br/pdf/tce/ v21n1/a15v21n1.pdf

4. Erdmann AL, Fernandes JD. Programas de pósgraduação em enfermagem no Brasil: desafios e perspectivas. Esc Anna Nery Rev Enferm [Internet]. 2011 [cited 2015 Jan 20]; 15(1):7-9. Available from:http://www.scielo.br/pdf/ean/v15n1/01.pdf

5. Carvalho V. Para uma epistemologia da enfermagem: tópicos de crítica e contribuição. Rio de Janeiro: Editora EEAN; 2013.

6. Santos QG, Azevedo DM, Costa RKS, Medeiros FP. A crise de paradigmas na ciência e as novas perspectivas para a enfermagem. Esc Anna Nery Rev Enferm [Internet]. 2011 [cited 2015 Fev 16]; 15(4):8337. Available from: http://www.scielo.br/pdf/ean/ v15n4/a24v15n4.pdf

7. Chalmers AF. What is this thing called science? $4^{\text {th }}$ ed. Brisbane (AU): University of Queensland Press; 2013.

8. American Association of Colleges of Nursing. Indicators of quality in research-focused doctoral programs in nursing. AACN Position Statement [Internet]. 2001 [cited 2015 Apr 14]. Available from: http://www.aacn.nche.edu/publications/position/ quality-indicators

9. Coordenação de Aperfeiçoamento de Pessoal de Nível Superior. Relatório de Avaliação 2007-2009. Trienal 2010. CAPES [Internet]. 2010 [cited 2015 Apr 15]. Available from:http://trienal.capes.gov.br/ wp-content/uploads/2010/09/ENFERMAGEM-rel11set10.pdf

10. Coordenação de Aperfeiçoamento de Pessoal de Nível Superior. Comunicado CAPES - período de avaliação do SNPG. [Internet] Brasília (DF): MEC; 2014 [cited 2015 May 4]. Available from: http:/ / www.capes.gov. $\mathrm{br} /$ component/content/article?id=7278:comunicadocapes-periodo-de-avaliacao-do-snpg

11. Backes DS, Backes MS, Lunardi VL, Erdmann $\mathrm{AL}$, Büscher A. Internacionalização como desafio ao impacto da globalização: contribuições da enfermagem. Rev Esc Enferm USP [Internet]. 2014 [cited 2015 Feb 16]; 48(5):772-7. Available from: http://www.scielo.br/pdf/reeusp/v48n5/pt_00806234-reeusp-48-05-772.pdf

12. Carvalho V. 40 anos da pós-graduação stricto sensu na EEAN/UFRJ: avanços e contribuições. Esc Anna Nery Rev Enferm [Internet]. 2012 [cited 2015 Feb 16]; 16(3):431-4. Available from:http://www.scielo.br/ pdf/ean/v16n3/01.pdf

13. Lakatos I. Falsification and the methodology of scientific research programs. In: Lakatos I, Criticism and the growth of knowledge. Cambridge: University Press; 1974.; p.20-6. 
14. Carvalho V. Por uma epistemologia do cuidado de enfermagem e a formação dos sujeitos do conhecimento na área da enfermagem - do ângulo de uma visão filosófica. Esc Anna Nery Rev Enferm [Internet]. 2009 [cited 2015 Apr 6]; 13 (2): 406-14. Available from: http://www.scielo.br/pdf/ean/ v13n2/v13n2a24.pdf

15. Carvalho V. Sobre construtos epistemológicos nas ciências - uma contribuição para a enfermagem. Rev Latino-am Enfermagem [Internet]. 2003 [cited 2015 Feb 16]; 11(4):420-8. Available from: http://www. scielo.br/pdf/rlae/v11n4/v11n4a03.pdf

16. Carvalho V. Enfermagem e história da enfermagem: aspectos epistemológicos destacados na construção do conhecimento profissional. Esc Anna Nery Rev Enferm [Internet]. 2007 [cited 2015 Apr 6]; 11(3):5008. Available from: http://www.scielo.br/pdf/ean/ v11n3/v11n3a16.pdf

17. Padilha MICS, Borenstein MS. História da enfermagem: ensino, pesquisa e interdisciplinaridade. Esc Anna Nery Rev Enferm [Internet]. 2006 [cited 2016 Feb 16]; 10 (3): 532-8. Available from: http:/ / www.scielo.br/ pdf/ean/v10n3/v10n3a24.pdf

18. Frello AT, Carraro TE. Contribuições de Florence Nightingale: uma revisão integrativa da literatura. Esc Anna Nery Rev Enferm [Internet]. 2013 [cited 2016 Feb 16]; 17 (3):573-9. Available from: http:/ / www.scielo. br/pdf/ean/v17n3/1414-8145-ean-17-03-0573.pdf

19. Gomes AMT. Entre Agostinho de Hipona e Florence Nightingale: o cuidado de enfermagem entrelaçado com o belo. Rev Enferm UERJ [Internet]. 2013 [cited 2016 Feb 16]; 21(esp.2):703-4. Available from: http://www.e-publicacoes.uerj.br/index.php/ enfermagemuerj/article/viewFile/12303/9582

20. Santos JLG, Pestana AL, Guerrero P, Meirelles BSH, Erdmann AL. Práticas de enfermeiros na gerência do cuidado em enfermagem e saúde: revisão integrativa. Rev Bras Enferm [Internet]. 2013 [cited 2016 Feb 16]; 66(2): 257-63. Available from: http://www.scielo.br/ pdf/reben/v66n2/16.pdf

21. Queirós PJP. Reflexões para uma epistemologia da enfermagem. Texto Contexto Enferm [Internet]. 2014 [cited 2015 Apr 6]; 23(3):776-81. Available from: http://www.scielo.br/pdf/tce/v23n3/pt_0104-0707tce-23-03-00776.pdf

22. Trzesniak P. Conferências com o espírito Solvay em áreas cientificamente emergentes: um impulso notável para a construção de conhecimento (ou: sabem o que a física disse para a ciência da enfermagem?). Rev Esc Enferm USP [Internet]. 2015 [cited 2015 Jun 8]; 49(2):184-6. Available from: http://www.scielo.br/pdf/reeusp/v49n2/pt_00806234-reeusp-49-02-0184.pdf

23. Bertolozzi MR, Padilha KG. Inovação e responsabilidade na formação e na pesquisa na América Latina. Rev Esc Enferm USP [Internet]. 2014 [cited 2015 Jun 8]; 48(2):200-5. Available from: http:/ / www.scielo.br/pdf/reeusp/v48n2/pt_0080-6234reeusp-48-02-200.pdf 